
JEA
Jurnal Eksplorasi Akuntansi
Vol. 1, No 3, Seri C, Agustus 2019, Hal 1151-1167
ISSN : 2656-3649 (Online)
http://jea.ppj.unp.ac.id/index.php/jea/issue/view/10

\title{
ANALISIS PERANAN KONSULTAN PAJAK TERHADAP KEPATUHAN WAJIB PAJAK DALAM MEMENUHI KEWAJIBAN PERPAJAKAN
}

\author{
Dian Khairannisa $^{1}$, Charoline Cheisviyanny, ${ }^{2}$ \\ 1) Alumni Jurusan Akuntansi Fakultas Ekonomi, Universitas Negeri Padang \\ 2)Jurusan Akuntansi Fakultas Ekonomi, Universitas Negeri Padang \\ *Korespondensi: diankhairannisa8@gmail.com
}

\begin{abstract}
This study aims to determine whether there is a role for tax consultants on taxpayer compliance in fulfilling tax obligations. This research is a type of qualitative research. Data collection techniques are semi-structured interviews and triangulation. Interviews were conducted with companies in the city of Padang. The population in this study were companies in the city of Padang, and 20 companies were sampled in this study. The result of this study prove that (1) the reasons for taxpayers using tax consultant services are divided into three, namely lack of knowledge of taxpayers regarding all tax regulations, complicated taxation systems and the last reason is that tax obligations can be carried out effectively and efficiently, (2) the type of tax consultant that is chosen by many corporate taxpayers is type honest consultant because taxpayers use tax consultants rather than aiming to help find loopholes but to help taxpayers who have difficulty managing their own taxes, and (3) advice from tax consultants chosen by all taxpayers are conservative advice, because companies do not want to bear the risk of using aggressive sanctions. For the next researcher, I suggest collecting data not only from interviews, but also suggested for further research to conduct research into a wider scope in various regions and add other variables related to the role of tax consultants for taxpayers in Indonesia.
\end{abstract}

Keywords: tax consultant; taxpayer; taxpayer compliance

How to cite (APA $6^{\text {th }}$ style)

Khairannisa, D., \& Cheisviyanny, C. (2019). Analisis Peranan Konsultan Pajak Terhadap Kepatuhan Wajib Pajak Dalam Memenuhi Kewajiban Perpajakan. Jurnal Eksplorasi Akuntansi, 1(3), Seri C, 1151-1167.

\section{PENDAHULUAN}

Pajak merupakan sumber utama penerimaan negara yang menyumbang sekitar $70 \%$ dari seluruh penerimaan negara. Tanpa pajak sebagian besar kegiatan dalam suatu negara akan sulit dilakukan. Penggunaan pajak seperti belanja pegawai, biaya pembangunan seperti jembatan, sekolah, rumah sakit dan lainnya itu semua ditanggung oleh pajak. Semakin banyak pajak yang dipungut maka akan semakin banyak infrastruktur yang dapat dibangun dalam suatu negara. Tidak dapat dipungkiri lagi bahwa sektor pajak mendapatkan perhatian yang luas dalam beberapa tahun terakhir. Peran pajak dalam APBN yang semakin meningkat membuat 
pemerintah harus melakukan berbagai upaya intensifikasi dan ekstensifikasi subjek dan objek pajak, sehingga keuangan negara senantiasa dalam kondisi sehat. Untuk itu, peran dan dukungan masyarakat sangatlah penting (Waluyo, 2008).

Pemungutan pajak di Indonesia mengacu pada sistem self assessment. Sistem self assessment adalah sistem pemungutan pajak yang memberi wewenang, kepercayaan, dan tanggungjawab kepada wajib pajak untuk menghitung, memperhitungkan, membayar, dan melaporkan sendiri besarnya pajak yang harus dibayar. Wajib pajak adalah orang pribadi atau badan meliputi pembayar pajak, pemotong pajak, dan pemungut pajak yang mempunyai hak dan kewajiban perpajakan sesuai dengan ketentuan peraturan perundang-undangan perpajakan. Konsekuensi sistem self assessment yaitu setiap wajib pajak yang memiliki penghasilan wajib mendaftarkan diri sendiri ke Kantor Pelayanan Pajak. Selanjutnya, setiap wajib pajak wajib menghitung sendiri dan membayar pajak yang terutang sesuai dengan ketentuan peraturan perundang-undangan perpajakan, dengan tidak menggantungkan pada adanya surat ketetapan pajak. Direktorat Jenderal Pajak tidak berkewajiban untuk menerbitkan surat ketetapan pajak atas semua Surat Pemberitahuan yang disampaikan wajib pajak. Penerbitan suatu surat ketetapan pajak hanya terbatas pada wajib pajak tertentu yang disebabkan oleh ketidakbenaran dalam pengisian Surat Pemberitahuan atau karena ditemukannya data fiskal yang tidak dilaporkan oleh wajib pajak. (Diana dan Setiawati, 2009:1)

Kepatuhan perpajakan merupakan masalah yang hampir dialami oleh semua negara yang menggunakan sistem perpajakan, baik itu pada negara berkembang maupun negara maju. Kepatuhan wajib pajak harus mendapatkan perhatian yang lebih bagi suatu negara, karena pajak memiliki peran yang besar terhadap sumber utama penerimaan negara. Menurut Syafrina (2013) para praktisi pajak mengatakan bahwa minimnya kepatuhan wajib pajak dapat dikarenakan oleh kurangnya pengetahuan pajak yang dimiliki oleh wajib pajak. Berikut ini adalah data rasio kepatuhan penyampaian SPT Tahunan PPh Tahun 2013-2017 di Indonesia.

Tabel 1

Rasio kepatuhan penyampaian SPT Tahunan PPh Tahun 2013-2017

\begin{tabular}{|l|c|c|c|c|c|}
\hline \multicolumn{1}{|c|}{ Uraian } & $\mathbf{2 0 1 7}$ & $\mathbf{2 0 1 6}$ & $\mathbf{2 0 1 5}$ & $\mathbf{2 0 1 4}$ & $\mathbf{2 0 1 3}$ \\
\hline $\begin{array}{l}\text { Wajib Pajak Terdaftar } \\
\text { Wajib SPT }\end{array}$ & 16.598 .887 & 20.165 .718 & 18.159 .840 & 18.357 .833 & 17.731 .736 \\
\hline a. Badan & 1.188 .488 & 1.215 .417 & 1.184 .816 & 1.166 .036 & 1.141 .797 \\
\hline b. Orang Pribadi Karyawan & 13.446 .068 & 16.817 .086 & 14.920 .292 & 14.455 .480 & 13.792 .052 \\
\hline $\begin{array}{l}\text { c. Orang Pribadi } \\
\text { Nonkaryawan }\end{array}$ & 1.964 .331 & 2.133 .215 & 2.054 .732 & 2.736 .317 & 2.797 .887 \\
\hline SPT Tahunan PPh & 12.057 .400 & 12.256 .401 & 10.975 .909 & 10.854 .819 & 9.967 .904 \\
\hline a. Badan & 776.292 & 707.167 & 681.828 & 552.959 & 546.372 \\
\hline b. Orang Pribadi Karyawan & 10.069 .911 & 10.612 .801 & 9.447 .275 & 9.659 .375 & 8.743 .128 \\
\hline $\begin{array}{l}\text { c. Orang Pribadi } \quad 1.211 .197 \\
\quad \text { Nonkaryawan }\end{array}$ & 936.433 & 846.806 & 642.485 & 678.404 \\
\hline Rasio Kepatuhan & $72,64 \%$ & $60,78 \%$ & $60,44 \%$ & $59,13 \%$ & $56,22 \%$ \\
\hline a. Badan & $65,32 \%$ & $58,18 \%$ & $57,55 \%$ & $47,42 \%$ & $47,85 \%$ \\
\hline b. Orang Pribadi Karyawan & $74,89 \%$ & $63,11 \%$ & $63,32 \%$ & $66,82 \%$ & $63,39 \%$ \\
\hline $\begin{array}{l}\text { c. Orang Pribadi } \\
\quad \text { Nonkaryawan }\end{array}$ & $61,66 \%$ & $43,90 \%$ & $41,21 \%$ & $23,48 \%$ & $24,25 \%$ \\
\hline
\end{tabular}

Sumber: Laporan Tahunan Direktorat Jenderal Pajak Tahun 2017 
Dari data di atas dapat dilihat bahwa rasio kepatuhan wajib pajak badan dalam memenuhi kewajiban perpajakan mengalami peningkatan setiap tahunnya walaupun pada tahun 2014 mengalami sedikit penurunan sekitar $0,43 \%$. Rasio kepatuhan wajib pajak orang pribadi karyawan menunjukkan persentase yang lebih tinggi dibandingkan dengan wajib pajak orang pribadi nonkaryawan. Pada tahun 2015 terjadi penurunan yang cukup signifikan yaitu sebesar 3,5\%. Namun peningkatan yang signifikan terjadi pada tahun 2017 yaitu meningkat sebesar 11,78\% dari persentase tahun 2016.

Dibandingkan tingkat kepatuhan wajib pajak orang pribadi karyawan, tingkat kepatuhan wajib pajak orang pribadi nonkaryawan lebih rendah. Hal ini dapat dilihat pada tahun 2013 tingkat kepatuhan hanya 24,25\% dan pada tahun 2014 mengalami penurunan menjadi 23,48\%. Namun pada tahun-tahun berikutnya terjadi peningkatan yang cukup signifikan sehingga tingkat kepatuhan wajib pajak orang pribadi nonkaryawan mencapai 61,66\%. Dapat disimpulkan bahwa tingkat kepatuhan wajib pajak badan lebih rendah daripada tingkat kepatuhan wajib pajak orang pribadi karyawan. Namun jika dibandingkan antara wajib pajak badan dengan wajib pajak orang pribadi nonkaryawan, tingkat kepatuhan lebih besar ditunjukkan oleh wajib pajak badan.

Tabel 2

Kepatuhan WP Pribadi dan WP Badan 2013-2016

\begin{tabular}{|c|c|c|c|c|c|c|}
\hline \multirow{2}{*}{ Tahun } & \multicolumn{2}{|c|}{ Jumlah WP } & Jumlah WP lapor SPT & \multicolumn{2}{c|}{ \%epatuhan } \\
\cline { 2 - 7 } & $\begin{array}{c}\text { WP } \\
\text { Pribadi }\end{array}$ & $\begin{array}{c}\text { WP } \\
\text { Badan }\end{array}$ & $\begin{array}{c}\text { WP } \\
\text { Pribadi }\end{array}$ & $\begin{array}{c}\text { WP } \\
\text { Badan }\end{array}$ & $\begin{array}{c}\text { WP } \\
\text { Pribadi }\end{array}$ & $\begin{array}{c}\text { WP } \\
\text { Badan }\end{array}$ \\
\hline 2013 & 141.656 & 15.532 & 65.251 & 4.842 & $46,06 \%$ & $31,17 \%$ \\
\hline 2014 & 149.911 & 16.210 & 73.669 & 4.902 & $49,14 \%$ & $30,24 \%$ \\
\hline 2015 & 159.217 & 17.129 & 80.886 & 5.334 & $50,80 \%$ & $31,14 \%$ \\
\hline 2016 & 167.894 & 17.907 & 60.227 & 3.561 & $35,87 \%$ & $19,89 \%$ \\
\hline
\end{tabular}

Sumber : diolah dari Seksi PDI KPP Pratama Padang Satu

Dari tabel di atas dapat dilihat bahwa jumlah wajib pajak badan yang lapor SPT lebih rendah daripada jumlah wajib pajak pribadi. Hal ini dapat dilihat dari persentase jumlah wajib pajak yang lapor SPT setiap tahunnya. Untuk wajib pajak pribadi jumlah wajib pajak yang lapor SPT mengalami peningkatan dari tahun 2013 sampai 2015. Pada Tahun 2013 jumlah wajib pajak lapor SPT sebanyak 65.251 dari 141.656 wajib pajak yang terdaftar. Untuk selanjutnya pada tahun 2014 dan 2015 jumlah wajib pajak yang lapor SPT mengalami peningkatan yaitu sebanyak 73.669 dan 80.886 dari 149.911 dan 159.217 jumlah wajib pajak terdaftar. Namun pada tahun 2016 jumlah wajib pajak lapor SPT mengalami penurunan dari tahun sebelumnya, yaitu mengalami penurunan sebesar $14,93 \%$.

Sementara itu untuk wajib pajak badan, persentase wajib pajak yang lapor SPT lebih rendah daripada wajib pajak pribadi. Pada tahun 2013 wajib pajak badan yang lapor SPT hanya sebesar $31,17 \%$ dan pada tahun berikutnya mengalami penurunan sebesar $0,93 \%$. Pada tahun 2015 jumlah wajib pajak badan yang lapor SPT kembali mengalami peningkatan, namun peningkatan yang terjadi tidak terlalu signifikan yaitu hanya sebesar 0,9\%. Namun pada tahun 2016 terjadi penurunan yang cukup signifikan yaitu sebesar 11,25\%.

Wajib pajak dapat memberikan kuasa kepada konsultan pajak untuk menangani kewajiban perpajakan, mulai dari mempersiapkan, menghitung hingga melaporkan pajak yang dibayarkan oleh wajib pajak. Penggunaan jasa konsultan pajak direkomendasikan untuk wajib pajak baik itu wajib pajak orang pribadi maupun wajib pajak badan. Menurut Lusiana dan Elisa 
(2013) konsultan pajak terbagi atas 3 tipe, yaitu creative consultant, honest consultant, dan cautios consultant. Saran konsultan pajak juga dapat mempengaruhi kepatuhan wajib pajak. Saran yang dapat diterima oleh wajib pajak dari konsultan pajak dapat dibagi menjadi dua, yaitu saran agresif dan saran konservatif. Wajib pajak dalam menentukan tipe konsultan pajak tergantung dari bentuk saran yang diharapkan dari konsultan pajak. Oleh karena itu, kita dapat melihat bagaimana saran serta tipe konsultan pajak dapat mempengaruhi wajib pajak dalam mematuhi kewajiban perpajakan.

Berdasarkan model pada Theory of Planned Behaviour (TPB) wajib pajak dapat mematuhi ketentuan perpajakan apabila ada niat (intention) di dalam diri wajib pajak tersebut. Niat seorang wajib pajak untuk mematuhi kewajiban perpajakan terbagi atas tiga faktor, yaitu Behavioral Beliefs, Normative Beliefs, dan Control Belief. Normatif Beliefs merupakan dorongan atau motivasi yang berasal dari luar diri seseorang (orang lain) yang akan mempengaruhi perilaku seseorang tersebut (Triyana, 2013). Selain Theory of Planned Behaviour, teori yang relevan pada penelitian ini yaitu teori atribusi. Menurut Suartana dalam Sumberjaya dan Anton (2017) teori atribusi mempelajari suatu proses bagaimana seseorang menginterpretasikan terjadinya suatu peristiwa, alasan, atau sebab perilaku. Perilaku secara internal adalah perilaku yang berada di bawah kendali individu, sedangkan perilaku secara eksternal adalah perilaku yang dipengaruhi dari luar individu.

Penelitian ini penting dilakukan karena masalah kepatuhan wajib pajak merupakan masalah utama dalam suatu negara. Jika tingkat kepatuhan dalam suatu negara rendah maka akan muncul tindakan penghindaran, penyelundupan, serta kelalaian pajak yang dapat merugikan negara itu sendiri, sehingga dengan adanya penelitian ini diharapkan dapat mengetahui apakah konsultan pajak memiliki pengaruh terhadap kepatuhan wajib pajak dalam memenuhi tanggungjawab perpajakan.

Perbedaan penelitian ini dengan penelitian-penelitian sebelumnya adalah peneliti lebih memfokuskan kepada pengaruh konsultan pajak terhadap kepatuhan wajib pajak, sementara pada penelitian-penelitian sebelumnya menggunakan faktor-faktor lain yang dapat mempengaruhi kepatuhan wajib pajak. Selain itu penelitian faktor konsultan pajak sebagai salah satu faktor yang mempengaruhi kepatuhan wajib pajak masih sedikit dan kebanyakan penelitian lebih meneliti pengaruh pelayanan fiskus terhadap kepatuhan wajib pajak. Perbedaan lainnya yaitu pada penelitian ini saya melakukan wawancara untuk menggali lebih dalam terkait peranan konsultan pajak terhadap kepatuhan wajib pajak.

Secara khusus tujuan dari penelitian ini yaitu untuk menyelidiki apakah ada hubungan antara saran yang ditawarkan oleh konsultan pajak dengan sikap kepatuhan wajib pajak terkait pembayaran pajak. Pemeriksaan literatur kepatuhan pajak mengungkapkan kurangnya perhatian penelitian mengenai dampak para konsultan pajak terhadap perilaku kepatuhan. Hasil penelitian ini akan mengungkapkan bagaimana saran yang diberikan oleh para konsultan pajak baik secara langsung maupun tidak langsung mempengaruhi tingkat kepatuhan pembayar pajak. Oleh karena itu peneliti ingin meneliti kembali faktor-faktor yang mempengaruhi kepatuhan wajib pajak dengan judul "Analisis Peranan Konsultan Pajak Terhadap Kepatuhan Wajib Pajak Dalam Memenuhi Kewajiban Perpajakan"

\section{REVIU LITERATUR DAN PENGEMBANGAN HIPOTESIS Teori Atribusi}

Menurut Suartana dalam Sumberjaya dan Anton (2017) teori atribusi mempelajari suatu proses bagaimana seseorang menginterpretasikan terjadinya suatu peristiwa, alasan, atau sebab perilaku. 
Perilaku secara internal adalah perilaku yang berada di bawah kendali individu, sedangkan perilaku secara eksternal adalah perilaku yang dipengaruhi dari luar individu. Maka dari itu, teori ini dianggap relevan digunakan pada penelitian ini karena untuk menjadi wajib pajak yang patuh dipengaruhi oleh faktor internal dan eksternal.

Teori atribusi sangat relevan digunakan pada penelitian ini. Karena keinginan wajib pajak untuk melaksanakan kewajiban perpajakan terkait dengan persepsi wajib pajak dalam membuat penilaian terhadap pajak itu sendiri. Persepsi wajib pajak dalam membuat penilaian terhadap sesuatu dalam hal ini perpajakan sangat dipengaruhi oleh faktor internal maupun eksternal dari orang tersebut.

\section{Theory of Planned Behavior (TPB)}

Menurut Triyana (2013) Theory of Planned Behavior (TPB) menjelaskan bahwa perilaku wajib pajak yang tidak patuh (non-compliance) sangat dipengaruhi oleh variable dari sikap, norma subyektif, serta kontrol keprilakuan yang dipersepsikan. Perilaku yang ditimbulkan oleh individu muncul karena adanya niat untuk berperilaku. Kepatuhan wajib pajak ditentukan berdasarkan persepsi wajib pajak terhadap seberapa pentingnya peranan konsultan pajak yang akan mendorong mereka untuk patuh terhadap kewajiban perpajakan. Hal ini juga dipengaruhi oleh kesadaran wajib pajak. Wajib pajak yang sadar pajak memiliki keinginan yang kuat untuk melakukan kewajiban perpajakan.

\section{Pajak}

Menurut Prof. Dr. Rochmat Soemitro,SH dalam Pudyatmoko (2008:1) pajak adalah iuran rakyat kepada kas negara berdasarkan undang-undang (yang dapat dipaksakan) dengan tidak mendapat jasa timbal (kontraprestasi), yang langsung dapat ditunjukkan dan yang digunakan untuk membayar pengeluaran umum. Menurut Dr.Soeparman Soemahamidjaja pajak adalah iuran wajib berupa uang atau barang yang dipungut oleh penguasa berdasarkan norma-norma hukum, guna menutup biaya produksi barang-barang dan jasa-jasa kolektif dalam mencapai kesejahteraan umum.

Pudyatmoko (2008: 9) menjelaskan bahwa pembagian pajak dapat dilihat dari sejumlah hal. Dari segi administratif yuridis pajak terbagi menjadi dua segi, yaitu segi yuridis dan segi ekonomis. Dari segi titik tolak pungutannya pajak terbagi menjadi dua jenis yaitu pajak subjektif dan pajak objektif. Berdasarkan sifatnya pajak terdiri dari pajak yang bersifat pribadi atau perorangan dan pajak yang bersifat kebendaan. Dan berdasarkan kewenangan pemungutannya pajak berdasarkan kewenangan pemungutannya terdiri dari pajak pusat dan pajak daerah

\section{Wajib Pajak}

Menurut Pudyatmoko (2008:22) di dalam ketentuan yang ada, khususnya di dalam UndangUndang Nomor 6 tahun 1983 sebagaimana telah diubah beberapa kali terakhir dengan UndangUndang Nomor 28 tahun 2007 tentang ketentuan umum dan tata cara perpajakan, wajib pajak adalah orang pribadi atau badan, meliputi pembayar pajak,pemotong pajak, dan pemungut pajak, yang mempunyai hak dan kewajiban perpajakan sesuai dengan ketentuan peraturan perundangundangan perpajakan. Berdasarkan PMK Nomor 229/PMK.03/2014 pasal 2 ayat 1 menjelaskan bahwa wajib pajak dapat menunjuk seorang kuasa dengan surat kuasa khusus untuk melaksanakan hak dan/atau memenuhi kewajiban sesuai dengan ketentuan peraturan perundangundangan di bidang perpajakan. 


\section{Kepatuhan}

Menurut Kamus Besar Bahasa Indonesia, kepatuhan adalah tunduk atau patuh pada ajaran atau aturan. Jadi kepatuhan dalam perpajakan berarti seseoang yang tunduk atau patuh terhadap Undang-Undang serta Peraturan Perpajakan dalam menjalankan kewajiban perpajakannya. Wajib pajak yang patuh berarti wajib pajak yang tidak memiliki tunggakan ataupun keterlambatan dalam menjalankan kewajibannya. Ada dua macam kepatuhan menurut Abdul dalam Syafrina (2013), yaitu kepatuhan formal dan kepatuhan material.

Kepatuhan formal merupakan suatu keadaan dimana wajib pajak memenuhi kewajiban secara formal sesuai dengan ketentuan dalam undang-undang perpajakan. Misalnya ketentuan batas waktu penyampaian SPT PPh Tahunan tanggal 31 Maret. Apabila wajib pajak telah melaporkan SPT PPh Tahunan sebelum atau pada tanggal 31 Maret maka wajib pajak telah memenuhi kepatuhan formal, akan tetapi isinya belum tentu memenuhi kepatuhan material. Sementara itu yang dimaksud dengan kepatuhan material yaitu suatu keadaan dimana wajib pajak memenuhi semua ketentuan material perpajakan, yakni sesuai dengan isi dan jiwa UndangUndang perpajakan. Kepatuhan material dapat juga meliputi kepatuhan formal. Kepatuhan pajak material memuat norma-norma yang menerangkan antara lain keadaan, perbuatan, peristiwa hukum yang dikenai pajak (objek pajak), siapa yang dikenakan pajak (sumber), berapa besar pajak yang dikenakan (tarif), segala sesuatu tentang timbul dan hapusnya utang pajak, dan hubungan hukum antara pemerintah dan wajib pajak.

\section{Kepatuhan Wajib Pajak}

Pengertian kepatuhan dalam kamus umum bahasa indonesia dalam Rahayu (2010:138), istilah kepatuhan berarti tunduk atau patuh pada ajaran atau aturan. Kepatuhan merupakan indikator penting dalam sistem pemungutan pajak di Indonesia. Menurut Sumberjaya dan Anton (2017) terdapat dua macam kepatuhan dalam perpajakan, yaitu kepatuhan formal dan kepatuhan material. Kepatuhan formal adalah keadaan wajib pajak memenuhi kewajiban perpajakan secara formal sesuai dengan ketentuan undang-undang perpajakan. Sedangkan kepatuhan material adalah keadaan wajib pajak secara hakikat memenuhi semua ketentuan material perpajakan.

\section{Konsultan Pajak}

Sesuai dengan Peraturan Menteri Keuangan Republik Indonesia Nomor 111/PMK.03/2014 tentang Konsultan Pajak Nomor 1, yang dimaksud dengan konsultan pajak adalah orang yang memberikan jasa konsultasi perpajakan kepada wajib pajak dalam rangka melaksanakan hak dan memenuhi kewajiban perpajakannya sesuai dengan peraturan perundang-undangan perpajakan. Menurut Diana dan Lilis (2009:103) konsultan pajak adalah setiap orang yang dalam lingkungan pekerjaannya secara bebas memberikan jasa profesional kepada wajib pajak dalam melaksanakan hak dan memenuhi kewajiban perpajakannya sesuai dengan peraturan perundang-undangan perpajakan yang berlaku. Peraturan Menteri Keuangan Republik Indonesia Nomor 229/PMK.03/2014 tentang Persyaratan serta Pelaksanaan Hak dan Kewajiban Seorang Kuasa Pasal 3 Konsultan Pajak dapat menerima kuasa dari Wajib Pajak Orang Pribadi dan atau/Wajib Pajak Badan sesuai dengan ketentuan peraturan perundang-undangan di bidang perpajakan. 


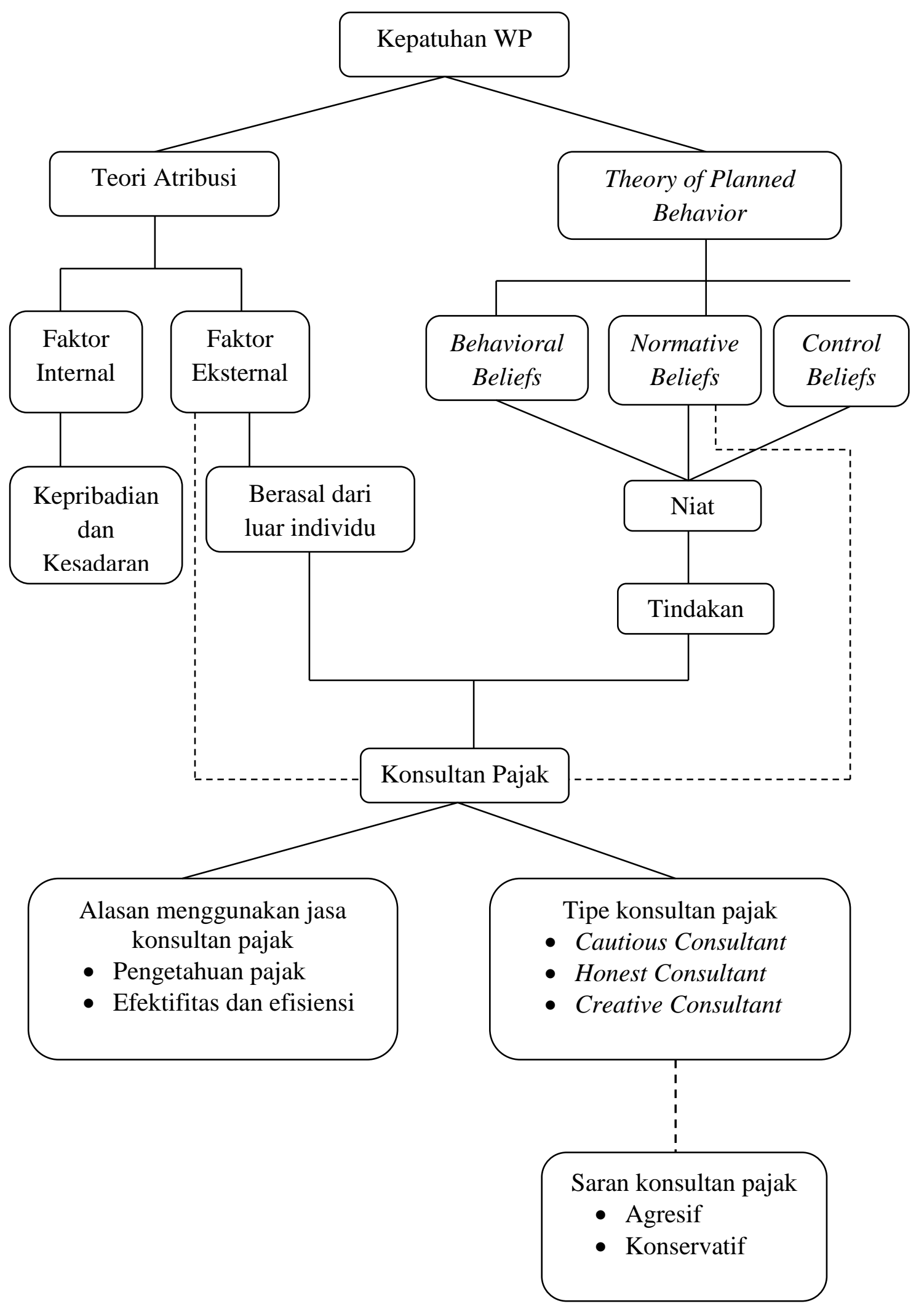

Gambar 3: Kerangka Konseptual 


\section{METODOLOGI PENELITIAN}

\section{Jenis Penelitian}

Jenis penelitian ini yaitu penelitian kualitatif, karena penelitian ini ditujukan untuk mendeskripsikan dan menganalisis fenomena, aktivitas sosial, sikap, kepercayaan, persepsi, peristiwa, serta pemikiran orang secara individu maupun kelompok. Penelitian kualitatif menurut Sugiyono (2014:9) adalah metode penelitian yang berlandaskan pada filsafat postpositivisme, digunakan untuk meneliti pada kondisi obyek alamiah, (sebagai lawannya adalah eksperimen) dimana peneliti adalah sebagai instrumen kunci, teknik pengumpulan data dilakukan secara gabungan, analisis data bersifat induktif/kualitatif, dan hasil penelitian kualitatif lebih menekankan makna daripada generalisasinya. Tujuan dari penelitian ini yaitu untuk menggambarkan dan mengungkap (to describe and explore) dan menggambarkan dan menjelaskan (to describe and explain). Penelitian ini mencoba untuk mendeskripsikan bagaimana pengaruh konsultan pajak terhadap kepatuhan wajib pajak.

\section{Tempat Penelitian}

Penelitian ini dilakukan pada perusahaan yang berdiri di Kota Padang. Pemilihan Perusahaan sebagai subjek penelitian dikarenakan tingkat rasio kepatuhan wajib pajak badan dikota padang dari tahun 2013 hingga 2016 lebih rendah daripada rasio kepatuhan wajib pajak orang pribadi. Bahkan tingkat kepatuhan tertinggi hanya sebesar $31,17 \%$. Serta mengalami penurunan yang sangat signifikan pada tahun 2016. Maka dari itu saya ingin melakukan penelitian pada perusahaan di Kota Padang untuk meneliti apakah rendahnya tingkat kepatuhan wajib pajak badan di Kota Padang ini dipengaruhi oleh ada atau tidaknya peranan konsultan pajak dalam membantu kewajiban perpajakan.

\section{Jenis data}

Terdapat 2 jenis data pada penelitian ini, yaitu data primer dan data sekunder. Data primer yang digunakan pada penelitian ini didapatkan dari hasil wawancara yang dilakukan dengan informan. Selanjutnya data yang diperoleh dari hasil wawancara tersebut akan dicocokkan dan dianalisis oleh peneliti. Inilah yang dimaksud dengan istilah triangulasi. Sementara itu, data sekunder yang digunakan pada penelitian ini diperoleh dari website resmi Direktorat Jenderal Pajak.

\section{Populasi dan Sampel Penelitian}

Menurut Sugiyono (2014:115) populasi yaitu wilayah generalisasi yang terdiri atas obyek/subyek yang mempunyai kualitas dan karakteristik tertentu yang diterapkan oleh peneliti untuk dipelajari dan kemudian ditarik kesimpulannya. Sampel yaitu bagian dari jumlah dan karakteristik yang dimiliki oleh populasi tersebut. Populasi pada penelitian ini yaitu perusahaan yang terdapat di Kota Padang. Sementara sampel dari penelitian ini yaitu 20 perusahaan yang terdapat di Kota Padang.

\section{Instrumen Penelitian}

Pada penelitian ini peneliti bertindak sebagai perencana, pengumpul data, analisis, penafsiran data, serta pelapor hasil penelitiannya. Jadi alat yang digunakan peneliti dalam melakukan penelitian ini yaitu peneliti itu sendiri yang dibantu dengan wawancara. 


\section{Teknik Pengumpulan Data}

Teknik pengumpulan data yang digunakan pada penelitian ini yaitu wawancara semi terstruktur (Semistructure Interview) dan triangulasi. Tujuan dari wawancara ini adalah untuk menemukan permasalahan secara lebih terbuka, dimana pihak yang diajak wawancara diminta pendapat dan ide-idenya. Triangulasi diartikan sebagai teknik pengumpulan data yang bersifat menggabungkan dari berbagai teknik pengumpulan data dan sumber data yang telah ada. Triangulasi yang digunakan pada penelitian ini yaitu triangulasi sumber data. Tujuan dari triangulasi bukan untuk mencari kebenaran tentang beberapa fenomena, tetapi lebih pada peningkatan pemahaman peneliti terhadap apa yang ditemukan.

\section{Teknik Analisis Data}

Menurut Sugiyono (2014:206) yang dimaksud dengan analisis data yaitu proses mencari dan menyusun secara sistematis data yang diperoleh dari hasil wawancara, catatan lapangan, dan dokumentasi, dengan cara mengorganisasikan data ke dalam kategori, menjabarkan ke dalam unit-unit, melakukan sintesa, menyusun ke dalam pola, memilih nama yang penting dan yang akan dipelajari, dan membuat kesimpulan sehingga mudah dipahami oleh diri sendiri maupun orang lain. Teknik analisis data pada penelitian ini yaitu sebagai berikut:

a. Pengumpulan data dari berbagai informan melalui wawancara dengan memastikan bahwa pertanyaan yang diajukan saat melakukan wawancara relevan dengan masalah yang akan diteliti.

b. Wawancara akan direkam jika mendapat persetujuan dari informan agar hasil wawancara lebih akurat.

c. Hasil wawancara akan dikelola oleh peneliti dan dianalisis secara individual.

d. Coding data wawancara disesuaikan dengan kerangka konseptual penelitian untuk memastikan bahwa hasil wawancara relevan dengan masalah yang akan diteliti. Tema utama akan dipecah menjadi tema khusus yang mana tema khusus tersebut menjelaskan dengan rinci terkait tema utama. Dengan dilakukannya penyesuaian tersebut maka hasil analisis dari penelitian ini tidak bersifat rancu sehingga dapat dipakai oleh teori yang digunakan pada penelitian ini.

e. Setelah dianalisis dan ditemukannya bahwa rumusan masalah sudah terjawab maka dibuatlah kesimpulan

\section{HASIL DAN PEMBAHASAN}

\section{Alasan Menggunakan Jasa Konsultan Pajak}

Pada umumnya wajib pajak menggunakan jasa konsultan pajak disebabkan oleh beberapa alasan, yaitu diantaranya kurangnya pengetahuan pihak terkait terhadap segala peraturan perpajakan, peraturan perpajakan yang rumit dan berbelit-belit, agar terhindar dari sanksi perpajakan, ingin lebih fokus dalam melakukan kegiatan atau kemajuan perusahaan, serta alasan-alasan lainnya dalam rangka mencapai kepatuhan perusahaan dalam hal perpajakan.

Dari hasil wawancara yang telah dilakukan dapat disimpulkan bahwa alasan wajib pajak menggunakan jasa konsultan pajak dalam mengurus kewajiban perpajakannya yaitu antara lain kurangnya pengetahuan wajib pajak mengenai segala peraturan perpajakan, sistem perpajakan yang rumit serta alasan terakhir yaitu agar kewajiban perpajakan dapat dilaksanakan dengan efektif dan efisien. Peraturan perpajakan yang rumit membuat wajib pajak mau tidak mau harus mempunyai pengetahuan dan pemahaman mengenai seluruh peraturan perpajakan di Indonesia. 
Wajib pajak yang memiliki pengetahuan pajak yang minim membutuhkan pihak lain untuk membantunya dalam mengurus peprpajakan, yaitu dengan menggunakan jasa konsultan pajak.

“.....ada beberapa hal yang kami kurang paham. Misalnya saja penyusunan SPT, faktur pajak, dan lainnya, itu kami kurang paham jadi kami serahkan ke konsultan pajak....." (Koresponden G)

Berdasarkan pendapat Fidel (2010) dan Thomas (2012) dalam (Syafrina, 2009) dapat dipahami bahwa jasa konsultan pajak bukan hanya membantu menyusun SPT melainkan lebih luas dan lebih kompleks, termasuk memberi nasehat, konsultasi, pelatihan, dan sosialisasi kepada wajib pajak. Kesemuanya ini dimaksudkan untuk meningkatkan pengetahuan wajib pajak dan pada akhirnya diharapkan akan meningkatkan kepatuhan mereka dalam melaksanakan kewajibannya sebagai warga negara yang taat pajak.

Penelitian mengenai pengetahuan wajib pajak juga pernah dilakukan oleh Ihsan (2013) yang mana pada penelitiannya menyimpulkan bahwa terdapat pengaruh positif dan signifikan pengetahuan wajib pajak terhadap kepatuhan wajib pajak badan di Kota Padang. Hal ini memberikan makna bahwa semakin tinggi pengetahuan wajib pajak badan maka semakin tinggi kepatuhan wajib pajak badan, sebaliknya semakin rendah pengetahuan wajib pajak badan maka semakin rendah pula kepatuhan wajib pajak badan.

Sistem perpajakan di Indonesia mempunyai peraturan yang cukup kompleks. Tidak hanya itu, peraturan perpajakan di Indonesia juga cenderung berubah-ubah serta kurang optimalnya sosialisasi dari otoritas perpajakan kepada wajib pajak membuat wajib pajak memerlukan bantuan pihak lain dalam menjalankan kewajiban perpajakannya.

“.....peraturan pajak itu kalau dilihat-lihat lumayan susah, sulit untuk memahaminya, dan lagian kalau ada konsultan pajak kita jadi bisa menyerahkannya ke konsultan pajak tanpa harus susah-susah untuk memahami aturan-aturan itu....." (Koresponden E)

Selain itu, perusahaan mengandalkan jasa konsultan pajak agar dapat memudahkan perusahaan dalam mengurus kewajiban perpajakan, sehingga perusahaan dapat lebih fokus untuk kegiatan lain, karena kegiatan dalam perusahaan bukan hanya pajak, terdapat masalah lain yang kompleks dalam perusahaan sehingga dengan adanya konsultan pajak perusahaan tetap dapat melanjutkan tugasnya terutama dalam hal pajak karena ada konsultan pajak yang membantu sehingga semuanya berjalan lebih efektif dan efisien.

“.....agar bisa memudahkan kami dalam mengurus perpajakan. Kita kan samasama tahu bahwa konsultan pajak itu sangat lihai dalam mengurus perpajakan, jadi ya supaya ga ribet, supaya kami bisa membayar pajak tepat waktu, supaya kami tidak melanggar aturan perpajakan ya tentu saja jasa konsultan pajak itu sangat penting bagi perusahaan kami....." (Koresponden I)

Dengan beberapa alasan yang telah dikemukakan oleh wajib pajak maka wajib pajak membutuhkan pihak yang dapat membantu dalam mengurus kewajiban perpajakannya, sehingga segala kegiatan perpajakan dapat terselesaikan dengan baik tanpa ada hambatan dan kendala. Pihak yang tepat dipilih oleh wajib pajak dalam membantu mereka yaitu konsultan pajak. 
Dengan menggunakan jasa konsultan pajak ini diharapkan dapat mengatasi kendala yang dihadapi wajib pajak saat ingin memenuhi kewajiban terkait pajaknya.

Hal ini dapat dilihat bahwa konsultan pajak banyak memberikan keuntungan bagi perusahaan yang menggunakan jasanya sehingga niat perusahaan untuk patuh terhadap perpajakan dengan menggunakan pihak luar dalam hal ini konsultan pajak akan tercapai. Banyak sekali keuntungan yang dirasakan oleh beberapa responden ketika menggunakan jasa konsultan pajak, yaitu diantaranya dapat mencarikan solusi yang tepat bagi perusahaan, dapat menjadikan perusahaan sebagai wajib pajak yang patuh terhadap perpajakan karena dengan menggunakan jasa konsultan pajak maka kewajiban perpajakan dapat dilakukan sesuai dengan peraturan perpajakan yang berlaku serta dapat juga menjalankannnya dengan tepat waktu.

\section{Tipe Konsultan Pajak}

Saat ini banyak wajib pajak yang menggunakan jasa konsultan pajak untuk membantu mereka dalam mengurus perpajakan, baik itu wajib pajak badan maupun wajib pajak orang pribadi. Oleh karena itu, wajib pajak harus selektif dalam memilih konsultan pajak yang akan digunakan dengan memilih kriteria sesuai dengan yang dibutuhkan. Berdasarkan hasil wawancara dari beberapa wajib pajak badan, wajib pajak menggunakan jasa konsultan pajak dengan beberapa tujuan, yaitu diantaranya untuk menghemat waktu dalam mengurus administrasi perpajakan, membantu dalam memenuhi kewajiban perpajakan agar sesuai dengan ketentuan yang berlaku dan terhindar dari sanksi perpajakan karena kurangnya pengetahuan wajib pajak terhadap perpajakan, serta berbagai tujuan lainnya.

Tipe konsultan pajak yang ingin digunakan oleh wajib pajak tergantung dari keinginan masing-masing perusahaan. Sakurai dan Braithwaite (2001) dalam Sutanto dan Elisa (2013) meneliti tentang 3 tipe konsultan pajak yaitu creative consultant, honest consultant, dan cautious consultant, yang mana pada penelitian ini menyatakan bahwa tipe konsultan pajak yang paling banyak dipilih adalah honest consultant karena konsultan pajak yang jujur dan dapat membantu wajib pajak dalam mematuhi peraturan merupakan hal yang paling penting bagi wajib pajak. Adanya 3 tipe konsultan pajak tersebut dikarenakan adanya tuntutan dari setiap pihak kepada konsultan pajak yaitu dari otoritas pajak yang mengutamakan konsultan pajak berperan dalam penegakan hukum dan bagi wajib pajak yang mengutamakan konsultan pajak membantu dalam meminimalkan pajak yang harus dibayarkan, dan asosiasi konsultan pajak yang mengutamakan setiap konsultan pajak menaati pedoman etika dalam menjalankan praktek untuk menjaga reputasi profesi.

Dari hasil wawancara dengan responden mengenai tipe konsultan pajak, wajib pajak lebih memilih untuk menggunakan konsultan pajak dengan tipe honest consultant dan cautious consultant, dan tidak ada satupun wajib pajak yang ingin memilih konsultan pajak dengan tipe creative consultant. Hal ini dikarenakan wajib pajak dalam memilih tipe konsultan pajak yang ingin mereka gunakan itu tergantung dari sikap mereka atau pandangan mereka terhadap kewajiban perpajakan. Jika wajib pajak memilih untuk menggunakan konsultan pajak dengan tipe creative consultant maka wajib pajak memiliki niat untuk menghindar dari kewajiban tersebut. Namun seluruh wajib pajak yang telah diwawancarai menolak untuk melakukan penghindaran pajak karena adanya ketakutan mereka untuk mendapatkan sanksi jika terbukti menghindar untuk membayar pajak.

Namun tidak hanya honest consultant, tipe konsultan pajak yang dipilih oleh perusahaan dalam membantu mereka memenuhi kewajiban perpajakanya, ada beberapa perusahaan yang lebih memilih menggunakan jasa konsultan pajak dengan tipe cautious consultant karena wajib 
pajak tersebut beranggapan bahwa tidak semua hal bisa dilakukan dengan cara yang jujur, tetapi ada beberapa hal yang membuat perusahaan melakukan kegiatan ataupun menjalankan kewajibannya dalam perpajakan secara fleksibel atau berdasarkan situasi yang terjadi di lapangan.

“.....alasannya ya karna ingin memperkecil jumlah pajak yang dibayar, kalau bisa sekecil mungkin ya, karna kalau bayar pajaknya jujur banget itu termasuk cukup besar menurut saya, dan agak berat gitu, jadi kalau bisa ya bagimanapun caranya perusahaan bisa kecil lah gitu jumlah pajak yang dilaporkan, maka dari itu kami butuh konsultan pajak dengan tipe ini, karna kan kalau memperkecil jumlah pajak sebenarnya tidak apa-apa asalkan masih berdasarkan peraturan....." (Koresponden F)

Dalam memilih konsultan pajak yang ingin digunakan oleh wajib pajak, maka mereka harus mengerti bagaimana seharusnya konsultan pajak yang tepat yang ingin digunakan dengan pengetahuan yang dimiliki oleh wajib pajak tersebut. Tipe konsultan pajak harus sesuai dengan keinginan perusahaan serta tipe perusahaan dalam menyikapi perpajakan. Perusahaan yang lebih memilih untuk menggunakan jasa konsultan pajak dengan tipe honest consultant dikarenakan perusahaan tersebut memutuskan untuk meminta bantuan konsultan pajak karena perusahaanperusahaan tersebut mengalami kesulitan jika mengurus pajaknya sendiri, bukan untuk maksud lain terutama untuk memperkecil jumlah pajak yang dibayar apalagi untuk menghindari pemenuhan kewajiban pajak.

“.....disini tujuan kami menggunakan konsultan pajak bukan untuk mencari cara untuk memperkecil jumlah pajak, tetapi untuk membantu kami mengurus pajak, tetap dengan jumlah yang sebenarnya dan kami butuh konsultan pajak untuk membantu perusahaan ini untuk menyelesaikan permasalahan-permasalahan kegiatan perpajakan.” (Koresponden X)

Selain itu, beberapa perusahaan lebih memilih untuk menggunakan jasa konsultan pajak dengan tipe honest consultant karena adanya ketakutan perusahaan untuk mendapatkan sanksi pajak jika melakukan tindakan memperkecil jumlah perpajakan, karena meminimalisir dianggap tindakan pelanggaran walaupun diperbolehkan dalam aturan, sehingga perusahaan lebih nyaman untuk melakukan kewajiban pajak dengan jujur.

“.....saya sih lebih memilih tipe konsultan pajak yang Honest Consultant, yang jujur. Namanya kita dagang pastinya mau jangka panjang, jadi ya kita ingin menghindari permasalahan dengan orang pajak atau dari pihak DJP supaya tidak ada pemeriksaan, supaya tidak ada kecurigaan, ya kalau bisa kan sejujur mungkin...." (Koresponden B)

Di antara tipe konsultan pajak honest consultant dan cautious consultant, wajib pajak cenderung lebih banyak memilih untuk menggunakan jasa konsultan pajak dengan tipe honest consultant. Dari 20 perusahaan yang diwawancara terdapat 15 perusahaan yang memilih untuk menggunakan konsultan pajak dengan tipe honest dan 5 perusahaan yang memilih tipe konsultan pajak cautious. Hal ini dikarenakan wajib pajak lebih memilih untuk bersikap jujur dan terbuka 
dalam hal perpajakan. Pada umumnya mereka berpendapat bahwa jika memilih untuk memperkecil jumlah pajak yang akan dibayar itu tidak akan memberikan keuntungan yang besar, dan tidak jauh berbeda jika harus membayar pajak dengan jumlah yang sebenarnya. Selain itu, alasan mereka memutuskan untuk menggunakan jasa konsultan pajak bukan untuk membantu mencari celah agar jumlah pajak yang disetor dapat diminimalisir, akan tetapi untuk membantu mereka dalam mengurus segala macam kegiatan pepajakan, oleh karena itu mereka cenderung untuk lebih memilih konsultan pajak dengan tipe honest consultant.

\section{Saran Konsultan Pajak}

Saran dari konsultan pajak dianggap dapat mempengaruhi kepatuhan dalam menjalankan kewajiban perpajakan bagi suatu wajib pajak. Hal ini dikarenakan wajib pajak dalam memilih untuk menggunakan konsultan pajak berdasarkan saran yang diberikan akan mempengaruhi sikap wajib pajak terhadap perpajakan. Wajib pajak yang memilih untuk menggunakan konsultan pajak yang cenderung memberikan saran yang bersifat konservatif itu berarti wajib pajak lebih memilih untuk patuh terhadap segala peraturan perpajakan tanpa memikirkan untuk melakukan penghindaran terhadap perpajakan. Namun jika wajib pajak lebih memilih untuk menggunakan konsultan pajak yang memberikan saran agresif maka itu berarti wajib pajak tersebut tidak patuh terhadap perpajakan karena lebih cenderung untuk berusaha menghindari kewajiban perpajakan.

Dalam menghadapi resiko dan pemenuhan kewajiban perpajakan yang sangat komplek, menyebabkan banyak wajib pajak yang mencari saran dari Konsultan Pajak, peran Konsultan Pajak disini diyakini dapat memfasilitasi wajib pajak dalam memenuhi kewajiban perpajakannya. Dari hasil wawancara dengan responden terkait jenis saran yang dipilih, semua wajib pajak lebih memilih untuk saran konservatif, karena mereka tidak ingin apabila perusahaan memilih menggunakan saran yang bersifat agresif maka perusahaan akan mendapatkan sanksi dari pihak perpajakan sehingga nantinya akan menimbulkan kerugian besar bagi perusahaan yang dapat membahayakan keberlangsungan perusahaan.

Dari hasil wawancara, semua wajib pajak lebih memilih saran konsultan pajak yang konservatif, hal ini dikarenakan wajib pajak lebih menginginkan untuk bersikap jujur dalam perpajakan dan lebih ingin mempertahankan serta mempercayai konsultan pajak yang cenderung memberikan saran konservatif. Dan jika ada saran yang bersifat konservatif dari konsultan pajak yang mungkin tidak bisa diterima oleh wajib pajak maka wajib pajak tersebut lebih cenderung untuk mendiskusikannya dengan konsultan pajak tanpa harus mengganti dengan konsultan pajak yang baru, karena mereka telah mempercayai konsultan pajak yang cenderung memberikan saran konservatif daripada konsultan pajak yang cenderung memberikan saran untuk melakukan penghindaran perpajakan.

“.....di perusahaan kami sangat menginginkan segala sesuatunya berjalan dengan jujur. Maka dari itu saya lebih memilih konsultan pajak yang cenderung memberikan saran yang konservatif, karna ya bagaimanapun saran yang konservatif lebih aman menurut saya dan saya benar-benar menghindari saran pajak yang agresif karna dapat membahayakan kelancaran perusahaan....." (Koresponden I)

Berdasarkan hasil wawancara, setelah diberikan suatu kasus mengenai saran agresif semua perusahaan menolak untuk menggunakan saran tersebut, karena perusahaan beranggapan bahwa saran agresif sangat membahayakan perusahaan. 
“....Itu ada sanksi pajaknya loh, dan sanksinya itu besar juga saya rasa, jadi bukannya untung malah rugi, niatnya mau untung sebesar-besarnya gitu kan, tapi nanti di akhir akan ketahuan dan malah lebih banyak ruginya daripada untungnya....." (Koresponden X)

Dengan saran agresif perusahaan akan mengalami kerugian besar karena mendapatkan sanksi yang besar sehingga kemajuan dan keberlangsungan perusahaan dapat terancam. Sehingga dapat dilihat bahwa tipe saran konsultan pajak yang ingin digunakan oleh suatu perusahaan akan berkaitan dengan tipe wajib pajak itu sendiri dalam menanggapi kewajiban perpajakannya. Jika perusahaan lebih memilih menggunakan saran konservatif itu berarti perusahaan memiliki keinginan untuk patuh terhadap pajak, dan sebaliknya jika perusahaan lebih memilih menggunakan saran agresif maka perusahaan tergolong wajib pajak tidak patuh karena berusaha untuk menghindari pajak dan melanggar aturan yang sudah ditetapkan.

\section{SIMPULAN, KETERBATASAN, DAN SARAN}

\section{Simpulan}

a. Alasan wajib pajak menggunakan jasa konsultan pajak terbagi atas tiga, yaitu kurangnya pengetahuan wajib pajak mengenai segala peraturan perpajakan, sistem perpajakan yang rumit serta alasan terakhir yaitu agar kewajiban perpajakan dapat dilaksanakan dengan efektif dan efisien.

b. Tipe konsultan pajak yang banyak dipilih oleh wajib pajak badan yaitu tipe honest consultant karena wajib pajak menggunakan konsultan pajak bukan bertujuan untuk membantu mencari celah akan tetapi untuk membantu wajib pajak yang mengalami kesulitan untuk mengurus pajak sendiri.

c. Saran konsultan pajak yang dipilih oleh semua wajib pajak yaitu saran konservatif, karena perusahaan tidak mau menanggung resiko jika menggunakan sanksi agresif.

\section{Keterbatasan}

a. Sumber data yang digunakan hanya melalui wawancara.

b. Karena keterbatasan biaya dan waktu, maka responden yang dipilih pada penelitian ini yaitu wajib pajak badan yang berada di Kota Padang. Oleh sebab itu, hasil penelitian ini tidak untuk digeneralisasikan terhadap keseluruhan wajib pajak badan yang ada di Indonesia.

\section{Saran}

a. Untuk peneliti selanjutnya saya sarankan untuk melakukan pengumpulan data bukan hanya dari wawancara.

b. Dengan keterbatasan pada penelitian ini, maka disarankan bagi penelitian selanjutnya untuk melakukan penelitian ke ruang lingkup yang lebih luas di berbagai kawasan serta menambah variabel lain terkait dengan peranan konsultan pajak bagi wajib pajak yang ada di Indonesia.

\section{DAFTAR PUSTAKA}

Allingham, Michael G \& Agnar Sandmo. 1972. Income Tax Evasion: A Theoretical Analysis. Jurnal of Public Economics I, 323-338

Boediono. (2003). Pelayanan Prima Perpajakan. Jakarta: PT Rineka Cipta

Burton, Richard. (2009). Kajian Aktual Perpajakan. Jakarta: Salemba Empat. 
Cheisviyanny, Charoline \& Herlina Helmy. 2014. Apakah Terdapat Perbedaan Tingkat Kepatuhan Antara Klien Konsultan Pajak Dengan Bukan Klien?. Jurnal WRA. Volume 2, No 1

Cloyd, C Bryan. 1995. The Effectof Financial Accounting Conformity on Reccomendations of Tax Preparers. The Journal of The American Taxation Association 50.

Cuccia, Andrew D, Karl Hackenbrack and Mark W Nelson. 1995. The Ability of Professional Standards to Mitigate Aggressive Reporting. The Accounting Review 227

Daniel, A. L. dan A. Meliala. (2009). Mengintip Kiprah Konsultan Pajak di Indonesia. Murai Kencana: Jakarta.

Darmayasa, I Nyoman\& Yuyung Rizka Aneswari. 2015. The Ethical Practice of Tax Consultant Based on Local Culture. Bali : Procedia-Social and Behavioral Sciences, 142-148

Devano, Sony dan Siti Kurnia Rahayu. (2006). Perpajakan, Konsep, Teori dan Isu. Jakarta: Prenada Media Group.

Devos, Ken. 2012. The Impact if Tax Proffesionals Upon The Compliance Behavior of Australian Individual Taxpayers. Australia: Revenue Law Journal. Volume 22,Issue 1

Diana, Anastasia \& Lilis Setiawati. (2009). Perpajakan Indonesia Konsep,Aplikasi dan Penuntun Praktis. Yogyakarta: CV Andi Offset

Duncan, William A, David W LaRue and Philip M J Reckers. 1989. An Emprical Examination of the Influence of Selected Economic and Non-Economic Variables on Decision Making By Tax Proffesionals. Advance in Taxation 91.

Fauzhi, Imamet al. 2015. Pengaruh Kualitas Jasa Konsultan Pajak dan Pengetahuan Pajak Terhadap Kepatuhan Wajib Pajak (Studi Pada Wajib Pajak Pengguna Jasa Kantor Konsultan Pajak Doni Budiono). Malang : Jurnal Administrasi Bisnis - Perpajakan $(J A B)$. Vol.4,No.1

Fikriningrum, Winda Kurnia. 2012. “Analisis Faktor-Faktor yang Mempengaruhi Wajib Pajak Orang Pribadi Dalam Memenuhi Kewajiban Membayar Pajak". Tidak diterbitkan. Fakultas Ekonomi. Universitas Diponegoro: Semarang

Fransiska, Imelda Pontoh, et al. 2017. Analisis Faktor-Faktor Yang Mempengaruhi Wajib Pajak Menggunakan Jasa Konsultan Pajak. Universitas Sam Ratulangi: Jurnal EMBA. Vol. 5, No. 2

Hidayat. 2013. Konsultan Pajak Nakal VS Konsultan Pajak Bijak. Jakarta. Jurnal Perpajakan Edisi 1.

Hite, Peggy A. \& Mcgill, Gary A. 1992. An Examination of Taxpayer Preference for Aggresive Tax Advice. National Tax Journal, Vol. 45, No. 4, pp 389-403

https://ekonomi.kompas.com/read/2018/02/28/170600426/tingkatkan-kesadaran masyarakat-djpgandeng-konsultan-pajak. "Tingkatkan Kesadaran Masyarakat, DJP Gandeng Konsultan Pajak", diakses 28 Februari 2018.

https://ekonomi.kompas.com/read/2019/01/09/064710526/banyak-ukm-gulung-tikar-karenamasalah-pajak. "Banyak UKM Gulung Tikar Karena Masalah Pajak", diakses 9 Januari 2019

Ihsan, Muchsin. 2013. "Pengaruh Pengetahuan Wajib Pajak, Penyuluhan Pajak, Kualitas Pelayanan Pajak, Dan Pemeriksaan Pajak Terhadap Kepatuhan Wajib Pajak Badan Di Kota Padang”. Tidak diterbitkan. Fakultas Ekonomi. Universitas Negeri Padang: Padang

Irawan, Candra. 2013. "Pengaruh Pengetahuan Wajib Pajak Tentang Peraturan Perpajakan, Penyelewengan Pajak dan Persepsi Wajib Pajak atas Kinerja Pelayanan Perpajakan 
Terhadap Motivasi Wajib Pajak dalam Memenuhi Kewajiban Perpajakan”. Jurnal. Universitas Riau.

Katuuk, Djuliana et al. 2017. Pengaruh Integritas dan Kreativitas Konsultan Pajak Terhadap Kepatuhan Wajib Pajak. Manado : Jurnal Riset Akuntansi Going Concern. Vol.12,No.2

Komara, A. 2014. Konsultan Pajak Agen Pemerintah atau Advokat Wajib Pajak. Indonesia Tax Review. Volume VII/edisi 17/2014

Kusuma, Tirta Hadi, et al. 2016. Pengaruh Persepsi Peran Etika dan Tanggungjawab Sosial, Sifat MACHIAVELLIAN, dan Preferensi Risiko Terhadap Pengambilan Keputusan Etis. Universitas Brawijaya: Jurnal Perpajakan. Vol.10, No.1

Luscombe, Mark A. 2004. Can Tax Professionals Be Creative Without Being Abusive?. Taxes 3

Munabari, Fadheil Wiza \& Andri Waskita Aji. 2014. Analisis Pengaruh Pengetahuan Perpajakan,Persepsi Tentang Kesulitan Pajak, dan Persepsi Tentang Account Representative Terhadap Minat Dalam Menggunakan Jasa Konsultan Pajak Pada Wajib Pajak Badan di KPP Pratama Bantul. Yogyakarta: Jurnal Akuntansi. Vol.2, No.2

Pudyatmoko, Sri. (2008). Pengantar Hukum Pajak. Yogyakarta: CV Andi Offset

Rizkilina, Pramita Aswari\& Dudi Pratomo. (2015). "Pengaruh Pengawasan dan Konsultasi Pajak dan Pemeriksaan Pajak Terhadap Tingkat Kepatuhan Pajak Penghasilan Badan Tahun 2011-2013 Pada KPP Madya Bandung. Bandung”: e-proceeding of management, 2(2)

Saraswati, Anggun Kurnia. 2012. "Analisis Faktor-Faktor Yang Mempengaruhi Kepatuhan Wajib Pajak Badan (Studi Empiris Pada Perusahaan Industri Yang Terdaftar Di Kantor Pelayanan Pajak Pratama Surakarta”). Tidak diterbitkan. Fakultas Ekonomi. Universitas Diponegoro: Semarang

Sakurai, Yuka \& Braithwaite, Valerie. 2001. Taxpayer's Perceptions of The Ideal Tax Adviser : Playing Safe or Saving Dollars?. Working Paper No. 5

Schisler, Dan L. 1994. An Experimental Examination of the Factors Effective Tax Preparers Aggressiveness - A Prospect Theory Approach. The Journal of The American Taxation Association 124

Spilker, Brian C, et al. 1999. "Tax Professionals" Interpretations of Ambiguity in Compliance and Planning Decision Contexts. The Journal of The American Taxation Association.

Sugianto, Hadi. 2017. Peran Konsultan Pajak Sebagai Partner Direktorat Jenderal Pajak dalam Sistem Pemungutan Pajak di Indonesia. Surabaya: Sekolah Tinggi Ilmu Ekonomi Indonesia (STIESIA)

Sugiyono. (2011). Metode Penelitian Kuantitatif, Kualitatif, dan R\&D. Bandung: ALFABETA

Sugiyono. (2012). Metode Penelitian Kualitatif dan R\&D. Bandung: Alfabeta CV

Sugiyono. (2014). Metode Penelitian Kualitatif dan R\&D. Bandung: Alfabeta CV

Sumarsan, Thomas. (2012). Tax Review dan Strategi Perencanaan Pajak. Jakarta: Indeks.

Sumberjaya, Eko\& Anton Arisman. 2017. "Pengaruh Pengetahuan Pajak, Sanksi Pajak, dan Peran Konsultan Pajak Terhadap Kepatuhan Wajib Pajak Usaha Mikro Kecil dan Menengah Di Kota Palembang (Studi Kasus KPP Pratama Palembang Ilir Barat”). Tidak diterbitkan. Fakultas Ekonomi. STIE MDP Palembang: Palembang

Sutanto,Lusiana \& Elisa Tjondro. (2013). "Persepsi Wajib Pajak Terhadap Konsultan Pajak dan Preferensi Wajib Pajak Dalam Memilih Konsultan Pajak: Honest Consultant, Creative Consultant, dan Cautious Consultant": Tax \& Accounting Review, 3(2).

Syarti,Syarfina.2013."Perbedaan Kepatuhan Antara Wajib Pajak Badan yang Menggunakan Jasa Konsultan dan Yang Mengurus Sendiri di Kota Padang”.Tidak diterbitkan. Fakultas Ekonomi. Universitas Negeri Padang: Padang 
Tiraada, Tryana A.M.. (2013). "Kesadaran Perpajakan, Sanksi Pajak, Sikap Fiskus Terhadap Kepatuhan WPOP di Kabupaten Minahasa Selatan": Jurnal EMBA, 1(3).

Toly, Agus Arianto \& Marisa Herryanto. (2013). "Pengaruh Kesadaran Wajib Pajak, Kegiatan Sosialisasi Perpajakan, dan Pemeriksaan Pajak terhadap Penerimaan Pajak Penghasilan di KPP Pratama Surabaya Sawahan”. Tax \& Accounting Review, 1(1).

Tomasic, Roman and Brendan Pentony. 1991. Taxation Law Compliance and The Role of Professional Tax Advisers'. Australian and New Zealand Journal of Criminology 241

Waluyo. (2008). Perpajakan Indonesia. Jakarta: Salemba Empat

Wade, Stacy \& Stephenson, Teresa. 2009. Do Taxpayers Want Less Aggresive Returns. The CPA Journal, Februari 2009. 